\title{
MULTIPLE DIRECTORSHIPS OF SHARI'AH COMMITTEES IN ISLAMIC BANKS: DO INTERNAL AUDIT AND FINANCIAL PERFORMANCE MATTER?
}

\author{
Yasin Ahmed Sulub \\ IIUM Institute of Islamic Banking and Finance \\ International Islamic University Malaysia, Kuala Lumpur, Malaysia \\ E-mail: sulub.yahmed@gmail.com \\ Saed Ahmed Sulub \\ Faculty of Business, Economics and Social Development \\ University Malaysia Terengganu, Kuala Terengganu, Malaysia \\ $\&$ \\ School of Graduate Studies, University of Hargeisa, Hargeisa, Somaliland \\ E-mail: saed_sulub@yahoo.com
}

\begin{abstract}
The paper examines whether governance characteristics and bank-specific attributes associate with the presence of the Shari'ah Committee (SC) members who hold multiple directorships in Islamic Banks (IBS). The paper utilizes a Logit Model in a sample of IBs in Sudan. The findings show that IBs with internal audit departments, high performance, and large debts are more likely to have SC members who sit on committees of other IBs. In contrast, the results reveal that bank size and board of directors' composition have no bearing upon the presence of directors with cross-memberships. There has been an ongoing debate on whether directors in conventional corporations' boardrooms should be restricted from sitting on multiple boards due to concerns over monitoring and oversight quality. However, the discussion on SC directors' multiple memberships has been scarce. Therefore, the paper provides a background for future research and helps stakeholders of the contemporary Shari'ah governance debate to understand the determinants of SC multiple directorships better.
\end{abstract}

Keywords: Shari'ah Committee, Multiple Directorships, Corporate Governance, Shari'ah Governance, Islamic Banks

\section{INTRODUCTION}

The emergence of the Corporate Governance (CG) debate in Islamic Financial Institutions (IFIs) coincided with the industry's fast-growing trend. The global Islamic banking industry's total assets grew from USD 1.746 billion in 2012 to USD 2.438 billion in 2017, and this growth is expected to increase further to USD 3.809 billion in 2023 (Thomson Reuters, 2018). Islamic Banks (IBs) adhere to the Islamic principles and rules (i.e., Shari'ah), and they differ from their conventional counterparts in terms of their functions, structure, and objectives (Mohammed \& Muhammed, 2017). The major difference that features the IBs from Conventional Banks (CBs) is the complete prohibition of interest ( $r i b a$ ) payment in transactions, the prohibition of operating 
or financing socially unethical activities such as gambling and alcohol (Abdul-Majid et al., 2010). Furthermore, IBs do not undertake in businesses that involve excessive speculation (Alam et al., 2017). Essentially, IBs must ensure compliance with the Shari'ah of their products, instruments, practices, and management (Hamza, 2013).

Hence, to govern these unique attributes, IBs, unlike CBs, besides the regular Board of Directors (BoDs), embrace an extra layer of the internal governance system in the form of Shari'ah committees (also known as Shari'ah boards) that thoroughly monitors and supervises IBs to guarantee Shari'ah-compliance (Grais \& Pellegrini, 2006; Safieddine, 2009; Mollah \& Zaman, 2015). In IFIs, Shari'ah governance refers to a mechanism led by Shari'ah principles and controlled by a religious board (i.e., a Shari'ah committee) to validate that these institutions' activities conform with the Shari'ah conducts and principles (Grassa, 2013). While the BoDs in IBs are liable to protect stakeholders' interests, a separate Shari'ah Committee (SC) is assigned to direct, review, and advice to ensure that the activities of IBs are according to Shari'ah rules (Isa \& Lee, 2020).

Although the expansion of IFIs over the last decades was followed by critical academic scrutiny that contributed to its development, some Shari'ah governance areas were kept overlooked (Sulub et al., 2020). It is worth mentioning that part of the debate in Shari'ah governance emerged with other CG developments around the world. However, an area that has been thoroughly discussed in CG debate in traditional board rooms, but not in IBs, is whether members of SC in an Islamic bank should be restricted from sitting on Shari'ah committees of other IBs/IFIs. Even the debate of multiple memberships of corporate board directors has not been immensely examined in IBs. A very few studies in the literature have, however, caught on this area in a broad context, discussing the implications of SC multiple directorships, which is hereafter referred to as "SCMD," for corporate reporting and disclosure (Wan Abdullah et al., 2015; Sulub et al., 2018a).

Prior CG debate linked multiple directorships at the board level with negative "abnormal returns" around the announcement of mergers and acquisitions (Ahn et al., 2010), lower firm value (Jiraporn et al., 2008), poor board meeting attendance (Jiraporn et al., 2009), weak CG (Fich \& Shivdasani, 2006), and lower financial performance (Devos et al., 2009; Lopez \& Rodriguez, 2014). Some of these studies argue that the negative implications of multiple directorships are pronounced when members of the board or its committees hold or exceed a certain number of other memberships (Ahn et al., 2010; Lopez \& Rodriguez, 2014; Hashim \& Rahman, 2011). The question that arises here, and that remains unanswered, is whether the conclusions of these studies can be generalized to SCMD in IBs. There are very few studies in the literature that associate SCMD with governance disclosures (Farook et al., 2011; Wan Abdullah et al., 2015; Sulub et al., 2018) and the establishment of an internal audit department (Sulub et al., 2020). Nevertheless, the debate on SCMD in IBs seems negligent.

Therefore, this paper aims to provide a general background for future studies and academicians about the importance of giving attention to multiple directorships in IBs' Shari'ah committees. We argue that any debate should begin with understanding the very nature of SCMD and what determines its incidence. Accordingly, we investigate governance and firmspecific factors that could theoretically associate with SCMD. Using a Logit model and a sample of Sudanese banks, we find that establishing an internal audit department, performance, and leverage are positively associated with the incidence of SCMD. Our results contribute to the current literature in two ways. First, we provide a framework for future studies about the 
importance of considering governance and firm-specific variables in the SCMD debate. Second, we inform the practitioners' debate of multiple directorships in Shari'ah governance.

\section{PREVIOUS STUDIES}

In IFIs, the quality and composition of the Shari'ah Committees are of crucial importance since the purpose of this type of institution is directly tied to compliance with religious principles. Prior research shows that Muslim populations are more likely to put an interest in IBs based on their religious beliefs (Kaabachi \& Obeid, 2017; Suhartanto et al., 2018), implying that noncompliance with these rulings could threaten the strategic performance of IBs. An area that has been frequently discussed in the context of traditional board rooms that could weaken governance bodies' performance is the holding of other directorships in other firms. However, this debate seems not to have been well extended to the Islamic banking context so far.

There are no studies in the literature on the determinants of multiple directorships in IBs. However, Sulub et al. (2018) showed that IBs with members who sit on more than one SC provide less information on CG. On the other hand, Grassa and Matoussi (2014) empirically demonstrated that members in SC with accounting/finance knowledge have a positive impact on the performance of IBs while interlocked SC members, i.e., members serving multiple boards, negatively affect the performance of IBs. This negative influence could be the effect of busy directors who hold multiple board seats in different IFIs. In contrast to the conclusions of this study, Isa and Lee (2020) found that SC members with finance/banking backgrounds and multiple directorships positively influence the performance of IBs because they are highly knowledgeable and confident about the product and market situation. Their study also reveals that members with Shari'ah qualifications and serving multiple boards are related to reduced risk-taking behavior, suggesting that such members are conservative in excessive risk-taking. This result could be the effect of reputable SC members (usually with multiple directorships) that may increase their credibility to customers, consequently lessening fund withdrawal risk and liquidity risk exposure (Safiullah \& Shamsuddin, 2018) and therefore enhancing performance.

In addition to that, the SC members might have motivations to exert independent oversight of Shari'ah-compliance to avoid reputation loss. Diamond (1989) asserts that reputation is an essential asset because it encourages decision-makers to be self-disciplined and refrains them from engaging in hazardous projects. Furthermore, the findings of Safiullah and Shamsuddin (2018) indicated that SC members with higher academic qualifications mitigate IBs' insolvency risk and operational risk, but the presence of SCMD tends to raise these risks. The study prescribes this as SC members who hold multiple directorships in various IFIs 'stretch' their time and efforts thinly over serving these institutions. Hence, their effective oversight of bank-level risk exposures could be compromised.

Most of the studies examining the determinants of SCMD are theoretical, and they explore issues such as the reasons for the incidence of SC cross-memberships across IFIs. For instance, Ali (2015) and Razak (2019) reported that the Islamic banking industry, during its inception in the early 1970s until the late 1990s, suffered from a shortage of Shari'ah scholars with strong Shari'ah law and finance expertise; this has prompted the IFIs to share similar Shari'ah scholars to serve in their Shari'ah committees (Majid \& Ghazal, 2012). However, the shortage of proficient Shari'ah scholars to justify the SCMD may not be accurate nowadays, where in fact, the industry possesses a sufficient number of competent Shari'ah scholars equipped with industry-relevant expertise (Razak, 2019). Hasan (2014) indicates that the absence 
of skilled Shari'ah scholars is, to a certain extent, not true. The incentive for IFIs to appoint certain reputable Shari'ah experts is predominantly to increase the marketability of their products and services. Garas (2012) also points out that IFIs generally desire top Shari'ah scholars (who are typically interlocking) because of their social reputation, which can function as an effective marketing tool to improve stakeholders' confidence and the IFI's reputation. Consequently, this has led to a concentration of Shari'ah board directorships amongst a specific group of scholars and neglecting other qualified and available scholars (Razak, 2019).

The issue of multiple directorships has been viewed from different perspectives. Based on the resource dependence theory, it is argued that directors with multiple board seats have access to more information and can bring external resources to the firm, allowing them to acquire new skills, education, and experiences obtained from the different boards they serve (Hundal, 2017). Similarly, SCMD in IFIs can expose the SC members to several Shari'ah debates and discussions on the legality of IFIs' different practices, which permits them to broaden their knowledge in Islamic law and enhance their experience (Farook \& Lanis, 2007; Farook et al.,2011; Islam \& Bhuiyan, 2021). On the contrary, formed on the busyness hypothesis, others assert that directors with multiple directorships that are overcommitted might become less effective corporate monitors due to busyness (Fich \& Shivdasani, 2006; Clements et al., 2015). Correspondingly, in the context of IFIs, having SC members with multiple board assignments might not have sufficient time and attention to fulfill their multiple board duties (Grassa \& Matoussi, 2014; Baklouti, 2020). Further, due to the director's access to each bank's strategic information, the SCMD may create confidentiality problems and a conflict of interest (Hamza, 2013; Hamdi \& Zarai, 2014) because of serving on the boards of the competitors.

Overall, In IFIs, the SC cross-directorships are common, and Siddiqui (2010) reported that there are enough Shari'ah experts, but IFIs prefer having well-known and prominent Shari'ah figures while potential Shari'ah advisors are not given a fair chance to serve on Shari'ah committees. Regardless, it is worth stressing that busy Shari'ah committees might imply that Shari'ah-compliance assurance could be at stake. SCMD could place an excessive burden on Shari'ah scholars as it can restrain the scholar's time commitment and attention to each IFI, hence putting the interest of both shareholders and stakeholders at risk (Razak, 2019). $\mathrm{SC}$ members must focus on dealing with the varying issues that could arise from Islamic banking dealings. For example, on the occasion of a Shari'ah-compliance problem, they will have to be ready to dedicate a tremendous amount of time in settling the issue and the possibility of neglecting their fiduciary obligations to other IFIs (Razak, 2019). Thus, SC members should occupy a reasonable number of directorships that will not impair their supervision and Shari'ahcompliance monitoring role.

There is no previous empirical research regarding the determinant factors of SCMD. Based on our initial observations, we test whether certain CG characteristics (BoDs and internal audit department) and bank-specific attributes (financial performance, debt, and bank size) associate with the incidence of multiple directorships in Shari'ah committees of IBs.

\section{DATA AND METHOD}

The paper tests the factors associated with the incidence of multiple memberships of directors in the Shari'ah Committees of IBs. We draw a sample of banks in a fully-fledged Islamic banking context (i.e., Sudan) based on data availability. The sample extends from 2009 to 2013, which is the period that preceded the introduction of the CG code at the Khartoum Exchange Market. We measure the dependent variable, i.e., SCMD, with a dummy variable which equals to 1 if any 
bank at any year has at least one member of SC who sits on another SC of another similar Islamic financial institution. To test the paper's objectives, we employed a Logit or logistic model, which is appropriate for this type of binary response variable. In other words, what differentiates the logistic regression from linear regression methods is using a binary choice when modelling a dichotomous dependent variable, thus applicable to this study. Because IBs did not disclose the independence of boards in Sudan prior to introducing the governance code in 2014, we used the proportion of non-executive directors as a measure of board strength (BODCOMP). Another governance mechanism that is tested here is the establishment of an IAD, which is measured by a dummy variable ( 1 if the bank has an IAD and 0 otherwise). Consistent with previous literature (Wan Abdullah et al., 2015; Sulub et al., 2018a; Sulub \& Salleh, 2019), we measured the financial performance with the return to equity ratio (ROE), leverage with debt to assets ratio (DEBT), and size with the natural logarithm of total assets (SIZE).

\section{Descriptive Tests and Bivariate Analysis}

\section{FINDINGS AND DISCUSSION}

Table 1 shows the descriptive and bivariate tests of the study variables. The average return on equity was 17 percent for the sample. While the mean for banks without SCMD [Group (1)] was 12 percent in the sample period, banks with SCMD [Group (2)] had a return of 18 percent on equity. The t-test shows that the difference is statistically significant ( $\mathrm{t}$ statistic $=-1.84, p<0.05)$. The results also show that the two groups' sizes are not significantly different $(p>0.1)$. While about half of IBs' assets in Sudan were financed by debt (DEBT) in the period, banks without SCMD had less DEBT (47 percent) than those with SCMD (56 percent). The difference is significant at the 10 percent level.

Table 1. Descriptive Tests and Bivariate Statistics

\begin{tabular}{|c|c|c|c|c|c|}
\hline \multirow[t]{2}{*}{ Variable } & \multirow[t]{2}{*}{$\begin{array}{l}\text { Mean } \\
\text { (Median) }\end{array}$} & \multirow[t]{2}{*}{ Std.dev } & \multicolumn{2}{|c|}{ Group Mean } & \multirow[t]{2}{*}{ t-test } \\
\hline & & & (1) & $(2)$ & \\
\hline \multicolumn{6}{|c|}{ Panel A: Continuous Variables } \\
\hline ROE & 0.17 & 0.11 & 0.12 & 0.18 & $-1.84 * *$ \\
\hline SIZE & 9.11 & 0.41 & 9.10 & 9.12 & -0.12 \\
\hline DEBT & 0.54 & 0.21 & 0.47 & 0.56 & $-1.28 *$ \\
\hline \multicolumn{6}{|c|}{ Panel B: Dichotomous Variables } \\
\hline & Yes & $\%$ & No & $\%$ & \\
\hline SCMD & 58 & 83 & 12 & 17 & \\
\hline BODCOMP & 46 & 66 & 24 & 34 & \\
\hline IAD & 48 & 69 & 22 & 31 & \\
\hline \multicolumn{6}{|c|}{$\begin{array}{l}\text { Notes: Observations }=70 ; \mathrm{SCMD}=1 \text { if there is at least one Shari'ah committee director who } \\
\text { holds another membership in another Islamic bank; BODCOMP } 1 \text { if all board members are } \\
\text { non-executives and } 0 \text { otherwise; IAD }=1 \text { if the banks have an internal audit department, } 0 \\
\text { otherwise; ROE= return on total equity; SIZE = natural log of total assets; DEBT= total debt to } \\
\text { total assets;(1) denotes banks without SCMD and (2) denotes banks with SCMD; ** and * } \\
\text { denote } 5 \% \text { and } 10 \% \text { significance levels, respectively. }\end{array}$} \\
\hline
\end{tabular}


Panel B of Table 1 describes the dummy variables. While IBs with SCMD were about four-fifth of the sample (58 firm-year observations), only 17 percent of the sample had no SCMD. For the Board Composition (BODCOMP), 46 percent of sample observations had only non-executive directors on board, and 24 percent comprised executive directors only. Similarly, about 69 percent of Sudanese banks had an established Internal Audit Function.

\section{Logistic Regression Analysis}

The output of the logistic regression model employed in the study is given in Table 2 . The test demonstrates some governance attributes and firm characteristics associated with the incidence of cross directorships in the Shari'ah Committees of IBs. While Model 1 runs the analysis without including time effects, Model 2 includes year dummies. The results of both models are qualitatively similar. The test is generally significant $\left[\mathrm{Chi}^{2}=16.99\right.$ (model 1 ), $\mathrm{Chi}^{2}=17.13$ (model 2), $p<0.000$ ] with Pseudo $\mathrm{R}^{2}$ of 0.264 and 0.267 , respectively. The Hosmer-Lemeshow test for both models is insignificant $(p>0.1)$, showing that the models fit the data well. To test the strength of the study variables included in the models, Wald Test shows that variables in both models are significant predictors $(p<0.05$ in model 1 and $p<0.1$ in model 2) of the incidence of SCMD. Furthermore, as the mean Variance Inflation Factor (VIF) in Table 2 shows, there are no Multicollinearity concerns in both models.

The paper investigates whether board composition (i.e., having non-executive directors on the board) is likely associated with the presence of SCMD. Although a positive sign is found, the relationship is not statistically significant $(\mathrm{p}>0.1)$. There are many possibilities of why the results are insignificant. First, Sudanese banks in the sample period did not disclose the independence of directors on the board. Therefore, the non-executives might not be independent, limiting their role in Shari'ah governance. These directories might be aligned with the management instead of aligning with shareholders' and stakeholders' interests, consequently impeding their judgments on Shari'ah governance matters. Theoretically, Independent nonexecutive directors play an important role in monitoring management (Fama, 1980; Fama \& Jensen, 1983) and are expected to bring independent views to the board and add to the diversity of skills and expertise of the directors (Abdullah, 2004). Thus, these directors may either advocate having SC members with multiple directorships that can bring external connections, social networks, experience, and skills or suggest less busy and available SC members who can engage in comprehensive Shari'ah-compliance assurance. In this case, although positively associated, it seems that the presence of non-executive directors on the board is insignificantly related to the incidence of SCMD. A possible explanation for this result could be that these directors may not be independent, therefore narrowing their involvement in Shari'ah governance, such as the process of appointing SC members.

Second, a large number of these directors might have been appointed to the board without considering their expertise and knowledge in Shari'ah governance. Thus, competency in Islamic law (i.e., Shari'ah), together with business, accounting, or finance knowledge, would help the board be highly independent in making decisions (Grassa \& Matoussi, 2014). Regardless of the reason for this insignificant relationship, it is clear that Shari'ah governance in the area of board composition is underdeveloped in the Sudanese banking context and needs further research.

The empirical results also demonstrate that banks with an established IAD are likely to have SC directors who sit on other IBs' committees $(p<0.05)$. The results may indicate that SC directors with other memberships are busy, overloaded, and might serve less frequently on Shari'ah committees. 
Table 2. Results of the Logit Model

\begin{tabular}{|c|c|c|c|c|}
\hline \multirow[t]{2}{*}{ Variable } & \multicolumn{2}{|l|}{ Model 1} & \multicolumn{2}{|c|}{ Model 2} \\
\hline & Coeff. & Z-Stat & Coeff. & Z-Stat \\
\hline BODCOMP & 0.74 & 0.97 & 0.75 & 0.97 \\
\hline IAD & 2.50 & $2.37 * *$ & 2.43 & $2.29 * *$ \\
\hline ROE & 1.36 & $2.73 * * *$ & 1.33 & $2.68 * * *$ \\
\hline DEBT & 3.58 & $1.70 * *$ & 3.58 & $1.68 *$ \\
\hline SIZE & -1.74 & -1.38 & -1.50 & -1.06 \\
\hline Constant & 16.79 & 1.39 & 14.91 & 1.41 \\
\hline $\mathrm{Chi}^{2}$ & $16.99 * * *$ & & $17.13^{* *}$ & \\
\hline Pseudo $^{2}$ & 0.264 & & 0.267 & \\
\hline Hosmer-Lemeshow & 67.00 & & 67.32 & \\
\hline Wald Test & $10.99 * *$ & & $11.28 *$ & \\
\hline Mean VIF & 1.23 & & 1.15 & \\
\hline Year Dummy & Not included & & Includec & \\
\hline \multicolumn{5}{|c|}{$\begin{array}{l}\text { Notes }=\text { Observations }=70 ; \text { Dependent Variable }(\mathrm{SCMD}): 1 \text { if there is at least one Shari'ah } \\
\text { committee director who holds another membership in another Islamic bank, and } 0 \text { otherwise; } \\
\text { BODCOMP }=1 \text { if all board members are non-executives and } 0 \text { otherwise; IAD }=1 \text { if the banks } \\
\text { have an internal audit department, } 0 \text { otherwise; } \mathrm{ROE}=\text { return on total equity (in log); DEBT }= \\
\text { total debt to total assets; SIZE = natural log of total assets; } * * *, * *, * \text { significant at } 1 \%, 5 \% \text {, and } \\
10 \% \text {, respectively. }\end{array}$} \\
\hline
\end{tabular}

Hence, banks with this type of directors may establish an internal Shari'ah review (or compliance) unit to facilitate Shari'ah compliance verification. The internal Shari'ah review unit focuses on and regularly examines IFI's compliance in all of its activities with Shari'ah, including contracts, products, transactions, policies, agreements, financial statements, and reports (Shafii et al., 2010; Shahzad et al., 2017; Islam et al., 2021). The Shari'ah review unit plays a significant role in ensuring that the operations of IBs are in line with Shari'ah rules, fatwas (Shari'ah opinions), guidelines, and rulings issued by the SC members (Bahari \& Baharudin, 2016).

Consequently, the major standard-setting organizations for IFIs, such as the Accounting and Auditing Organization for Islamic Financial Institutions (AAOIFI) and the Islamic Financial Services Board (IFSB), suggest that IBs should undertake an internal Shari'ah review and establish an independent unit that is responsible for such task (see, AAOIFI, 2015; IFSB, 2009). Moreover, AAOIFI's Governance Standard No. 3 suggests that the head of the internal Shari'ah review shall be responsible to the board of directors (AAOIFI, 2015) to ensure independence from the bank's management and ascertain effective oversight of Shari'ah-compliance. Besides, the Shari'ah review unit usually serves as a referral point for the internal audit department to confirm and clarify Shari'ah-related issues (Yazkhiruni al., 2018).

Shari'ah non-compliance in IBs can damage stakeholders' confidence, disrupting the stability of the IBs (Haqqi, 2014; Ali \& Hassan, 2019). Also, non-compliance with Shari'ah can lead to fund withdrawals and cancellation of investment contracts which can cause a downturn in performance and increase the risk of IBs (Hamza, 2013). In fact, prior studies such as Abduh (2011) and Lee and Ullah (2011) have shown that customers of IBs are willing to withdraw their funds in case of Shari'ah non-compliance occurrence. On that account, since the results suggest 
that IBs with an IAD are likely to have SC with multiple directorships that can be overcommitted and thus, the possibility of neglecting their fiduciary duties, a dedicated internal Shari'ah review/compliance unit can accommodate the respective banks' need to verify that Shari'ahcompliance has been satisfied accurately. Implementing an internal Shari'ah review is essential since it is an integral part of the IFIs' governance mechanism (Kasim et al., 2013) to ensure the credibility and viability of IFIs because of the requirement for IBs to adhere to the Shari'ah principles (Li et al., 2014). On the other hand, AAOIFI and IFSB also recommend an external Shari'ah auditing to ensure a rigorous and more independent Shari'ah-compliance assessment.

Moreover, confirming the results of the bivariate above tests, Table 2 reveals that financial performance partially explains the incidence of SCMD. IBs with higher ROE are more likely to have members on SC who sit on other committees of other IBs $(p<0.05)$. This might imply that directors with SCMD are reputable, experienced scholars who can only be afforded by highly performing IBs. This result is consistent with Ferris et al. (2003), who found that financial performance positively influences the number of appointments held by a director and the likelihood of an appointment to a new board. Their findings also suggest that reputation matters for the number of directorships held by a director. The number of directorships held by a director might be a proxy for reputational capital, with such individuals regarded as high-quality directors (Kaplan \& Reishus, 1990; Vafeas, 1999). Likewise, the market for SC directors may perceive SCMD as beneficial to the IFI in terms of the quality of their monitoring and their vast experience, thus encouraging IFIs to recruit SC members that hold multiple directorships. Moreover, for the IFIs to have top Shari'ah figures on their Shari'ah committees can significantly contribute to attracting potential customers, especially the pious ones, due to the wide popularity attained by these scholars within the pious segment of the market (Godlewski et al., 2014; Berg et al., 2016). In other words, the advantage of appointing Shari'ah scholars who serve multiple boards is their reputation, where a senior Shari'ah scholar earns more respect and enjoys an extensive reputation within society (Razak, 2019).

Nevertheless, it should be noted that having top Shari'ah characters in SC does not necessarily guarantee optimal Shari'ah-compliance monitoring of IFIs (Razak 2019). The SC members must make certain that they have the time and commitment to prepare and attend the meetings of the respective IFIs in which they hold directorships (Abidin et al., 2020). Concerning this, Hasan (2014) draws attention that SC members should limit the number of their appointments due to time constraints. Indeed, SC members must have the devotion of time, attention, and diligence necessary to discharge their responsibilities thoroughly since they are responsible for catering to the IBs' need to comply with Shari'ah. For instance, in the case of Shari'ah non-compliance event of any transaction, the returns of such transactions are declared void and credited to the bank's charity accounts (Ayub et al., 2019). Such Shari'ah noncompliant income will be discarded from the banks' books, resulting in net losses on these transactions for the Islamic bank (Basiruddin \& Ahmed, 2019), hence the need for available and capable SC members. Also, Shari'ah non-compliance can damage the reputation of IBs and decrease the confidence of depositors, investors, customers, and other stakeholders (Nawaz et al., 2020).

Furthermore, the findings show that highly leveraged banks are more likely to include members with cross-membership. The relationship is significant at the 5 percent level in Model 1 and the 10 percent level in Model 2. Highly leveraged banks may appoint interlocking SC members to enhance their creditworthiness. Razak (2019) highlights that certain IFIs prefer 
assigning top Shari'ah figures into their Shari'ah committees who bring more added value to the institution in terms of reputation and creditability. Moreover, Baklouti (2020) emphasizes that having well-reputable SC members attracts a significant number of customers and depositors, which can reduce the liquidity risk of IBs. As a result, these factors may lead customers to entrust and lend their money to these IBs, facilitating these banks' access to higher capital.

On the other hand, it seems that the bank's size does not matter for the bank to have this type of SC members as the coefficient of size is insignificant $(p>0.1)$ in both models of Table 2. This result is inconsistent with Ferris et al. (2003), who concluded that firm size has a significantly positive effect on cross-memberships. Their study suggests that multiple board directorships are a large-firm phenomenon because larger firms contract with a wider environment and require negotiations with more parties; therefore, interlocking directors permit the firm to solidify the contracting relations with other firms. In this study's context, a possible rationale behind this result might be that the sample banks' size is small for these banks to have or even attain top SC members who serve multiple Shari'ah committees of various IFIs. Besides, it is possible that the size effect is irrelevant for the incidence of SCMD due to the insignificant difference between the sizes of the sample banks, as shown in descriptive test results.

\section{CONCLUDING REMARKS}

Numerous studies have extensively discussed multiple directorships of BoDs in conventional banking settings. Nonetheless, the debate on cross-memberships in IBs is still limited. In particular, understanding what determines the incidence of multiple directorships in the Shari'ah Committee has not been examined. Therefore, we tested whether the presence of an IAD, financial performance, the BoDs' composition, and some bank characteristics were associated with the incidence of multiple directorships in Shari'ah committees of IBs. We used data from a sample of Sudanese IBs and a logistic regression to achieve this objective.

We show that the establishment of IAD is positively associated with the incidence of SC members who sit on other boards. The findings also revealed that IBs with higher financial performance and larger debts are more likely to have members with multiple directorships. This result has important implications for regulators and the literature. First, it is useful to consider the CG and firm-specific factors that could associate with the incidence of SCMD and corporate board directors' multiple directorships across IFIs. Second, we emphasize the ongoing debate on the practice of SCMD and contribute to the Shari'ah governance literature.

However, this study provides preliminary evidence and draws attention to the importance of studying issues related to multiple directorships of Shari'ah committees in IBs. We recommend future research to extend the data period and setting and to examine other governance variables.

\section{REFERENCES}

Abidin, N. H. Z., Yasin, F. M., \& Abidin, A. Z. (2020). Independence from the perspective of the Shari'ah committee. Asian Journal of Accounting Research, Vol. ahead-of-print No. ahead-of-print. https://doi.org/10.1108/AJAR-07-2020-0053

Abd Razak, A. H. (2019). Multiple Sharia' board directorship: a Maslahah (public interest) perspective. Journal of Islamic Marketing, 11(3), 745-764. 
Abduh, M. (2011). Islamic banking service quality and withdrawal risk: The Indonesian experience. International Journal of Excellence in Islamic Banking and Finance, 1(2), 115.

Abdullah, S. N. (2004). Board composition, CEO duality and performance among Malaysian listed companies. Corporate Governance: The international journal of business in society, 4(4), 47-61.

Abdul-Majid, M., Saal, D. S., \& Battisti, G. (2010). Efficiency in Islamic and conventional banking: an international comparison. Journal of productivity analysis, 34(1), 25-43.

Accounting, Auditing and Governance Standards for Islamic Financial Institutions (AAOIFI) (2015). Accounting, Auditing and Governance Standards for Islamic Financial Institutions, Bahrain: AAOIFI

Ahn, S., Jiraporn, P., \& Kim, Y. S. (2010). Multiple directorships and acquirer returns. Journal of Banking \& Finance, 34(9), 2011-2026.

Alam, N., Gupta, L., \& Shanmugam, B. (2017). Prohibition of Riba and Gharar in Islamic banking. In Islamic Finance (pp. 35-53). Palgrave Macmillan, Cham.

Ali, A. J. (Ed.). (2015). Handbook of research on Islamic business ethics. Edward Elgar Publishing. https://doi.org/10.4337/9781781009451

Ali, M. Y., \& Hassan, F. (2019). The Study of Potential Shariah Non-Compliance Risks in Murabahah Along with Their Risk Management. Journal of Finance and Economics Research, 4(1), 44-58.

Ayub, M., Khan, K., Rashid, D., Shahzad, M. A., \& Rehman, H. (2019). Enhancing the competence and effectiveness of Sharī 'ah advisory boards: Case of Islamic banking institutions in Pakistan. Journal of Islamic Business and Management, 9(1), 42-63.

Bahari, N. F., \& Baharudin, N. A. (2016). Shariah Governance Framework: The Roles of Shariah Review and Shariah Auditing. In Proceeding of the $3^{\text {rd }}$ International Conference on Management \& Muamalah, Vol. 2016, 375-382. Retrieved from http://conference.kuis.edu.my/icomm/3rd/eproceedings/IC-037.pdf

Baklouti, I. (2020). Is the Sharia supervisory board a friend or an enemy of Islamic banks?, Journal of Islamic Marketing, Vol. ahead-of-print No. ahead-ofprint.https://doi.org/10.1108/JIMA-04-2020-0118

Basiruddin, R., \& Ahmed, H. (2019). Corporate governance and Shariah non-compliant risk in Islamic banks: evidence from Southeast Asia. Corporate Governance: The International Journal of Business in Society, 20(2), 240-262.

Berg, N., El-Komi, M., \& Kim, J. Y. (2016). Market segmentation and non-uniform Shariah standards in Islamic finance. Journal of Economic Behavior \& Organization, 132, 39-49. 
Clements, C., Neill, J. D., \& Wertheim, P. (2015). Multiple directorships, industry relatedness, and corporate governance effectiveness. Corporate Governance: The International Journal of Business in Society, 15(5), 590-606.

Devos, E., Prevost, A., \& Puthenpurackal, J. (2009). Are interlocked directors effective monitors?. Financial Management, 38(4), 861-887.

Diamond, D. W. (1989). Reputation acquisition in debt markets. Journal of Political Economy, 97(4), 828-862.

Fama, E. F. (1980). Agency problems and the theory of the firm. Journal of Political Economy, 88(2), 288-307.

Fama, E. F., \& Jensen, M. C. (1983). Separation of ownership and control. The Journal of Law and Economics, 26(2), 301-325.

Farook, S. \& Lanis, R. (2007).Banking on Islam? Determinants of corporate social responsibility disclosure, Advances in Islamic Economics and Finance: Proceedings of $6^{\text {th }}$ InternationalConference on Islamic Economics and Finance, Jeddah, pp. 217-247.

Farook, S., Hassan, M. K., \& Lanis, R. (2011). Determinants of corporate social responsibility disclosure: the case of Islamic banks. Journal of Islamic Accounting and Business Research, 2(2), 114-141.

Ferris, S. P., Jagannathan, M., \& Pritchard, A. C. (2003). Too busy to mind the business? Monitoring by directors with multiple board appointments. The Journal of Finance, 58(3), 1087-1111.

Fich, E. M., \& Shivdasani, A. (2006). Are busy boards effective monitors?. The Journal of Finance, 61(2), 689-724.

Garas, S. N. (2012). The control of the Shari'a Supervisory Board in the Islamic financial institutions. International Journal of Islamic and Middle Eastern Finance and Management, 5(1), 8-24.

Godlewski, C. J., Turk-Ariss, R., \& Weill, L. (2016). Do the type of Sukuk and choice of shari'a scholar matter?. Journal of Economic Behavior \& Organization, 132, 63-76.

Grais, W., \& Pellegrini, M. (2006). Corporate governance in institutions offering Islamic financial services: issues and options. The World Bank.

Grassa, R. (2013). Shariah supervisory system in Islamic financial institutions. Humanomics, 29(4), 333-348. 
Grassa, R., \& Matoussi, H. (2014). Is corporate governance different for Islamic banks? A comparative analysis between the Gulf Cooperation Council and Southeast Asian countries. International Journal of Business Governance and Ethics, 9(1), 27-51.

Hamdi, F. M. \& Zarai, M. A. (2014). Corporate governance practices and earnings management in Islamic banking institutions, Research Journal of Finance and accounting, 5(9),81-96.

Hamza, H. (2013). Sharia governance in Islamic banks: effectiveness and supervision model. International Journal of Islamic and Middle Eastern Finance and Management, $6(3), 226-237$.

Haqqi, A. R. A. (2014). Shariah governance in Islamic financial institution: An appraisal. USChina L. Rev., 11, 112.

Hasan, Z. (2014). In search of the perceptions of the Shari'ah scholars on Shari'ah governance system. International journal of Islamic and Middle Eastern finance and management, $7(1), 22-36$.

Hashim, H. A., \& Rahman, M. S. A. (2011). Multiple board appointments: are directors effective?. International Journal of Business and Social Science, 2(17), 137-144.

Hundal, S. (2017). Multiple directorships of corporate boards and firm performance in India. Hundal, S.(2017). Multiple directorships of corporate boards and firm performance in India. Corporate Ownership \& Control, 14(4), 150-164.

Isa, M., \& Lee, S. P. (2020). Does the Shariah committee influence risk-taking and performance of Islamic banks in Malaysia?. Journal of Islamic Accounting and Business Research, 11(9), 1739-1755.

Islamic Financial Services Board (2009). Guiding principles on Sharī’ah governance systems for Institutions offering Islamic financial services. Islamic Finance Services Board, Malaysia.

Islam, K. M. A, Sadekin, M. S., Rahman, M. T., \& Chowdhury, M. A. H. (2021). The Impact of Shariah Supervisory Board and Shariah Audit Committee on Corporate Social Responsibility Adoption at Islamic Banks in Bangladesh. The Journal of Asian Finance, Economics and Business, 8(3), 479-485.

Islam, K. M. A, \& Bhuiyan, A. B. (2021). Determinants of the Effectiveness of Internal Shariah Audit: Evidence from Islamic Banks in Bangladesh. The Journal of Asian Finance, Economics, and Business, 8(2), 223-230.

Jiraporn, P., Davidson III, W. N., DaDalt, P., \& Ning, Y. (2009). Too busy to show up? An analysis of directors' absences. The Quarterly Review of Economics and Finance, 49(3), $1159-1171$. 
Jiraporn, P., Kim, Y. S., \& Davidson III, W. N. (2008). Multiple directorships and corporate diversification. Journal of Empirical Finance, 15(3), 418-435.

Kaabachi, S., \& Obeid, H. (2016). Determinants of Islamic banking adoption in Tunisia: empirical analysis. International Journal of Bank Marketing, 33(6), 786-807.

Kaplan, S. N., \& Reishus, D. (1990). Outside directorships and corporate performance. Journal of Financial Economics, 27(2), 389-410.

Kasim, N., Nu Htay, S. N., \& Salman, S. A. (2013). Comparative analysis on AAOIFI, IFSB and BNM Shari'ah governance guidelines. International Journal of Business and Social Science, 4(15), 220-227.

Lee, K. H., \& Ullah, S. (2011). Customers' attitude toward Islamic banking in Pakistan. International Journal of Islamic and Middle Eastern Finance and Management, 4(2), 131-145.

Li, Y., Armstrong, A., \& Clarke, A. (2014). Relationships of corporate governance mechanisms and financial performance in Islamic banks: a meta-analysis. Journal of Law and Governance, 9(1), 50-63.

López Iturriaga, F. J., \& Morrós Rodríguez, I. (2014). Boards of directors and firm performance: the effect of multiple directorships. Spanish Journal of Finance and Accounting/Revista Española de Financiación y Contabilidad, 43(2), 177-192.

Majid, M. Z. A., \& Ghazal, R. (2012). Comparative analysis of Islamic banking supervision and regulation development. Money and Economy, 6(3), 114-162.

Mohammed, S. A. S. A. N., \& Muhammed, D. J. (2017). Financial crisis, legal origin, economic status and multi-bank performance indicators. Journal of Applied Accounting Research, $8(2), 208-222$.

Mollah, S., \& Zaman, M. (2015). Shari'ah supervision, corporate governance and performance: Conventional vs. Islamic banks. Journal of Banking \& Finance, 58, 418-435.

Nawaz, T., Haniffa, R., \& Hudaib, M. (2020). On intellectual capital efficiency and shariah governance in Islamic banking business model. International Journal of Finance \& Economics. Early View. https://doi.org/10.1002/ijfe.1986

Safieddine, A. (2009). Islamic financial institutions and corporate governance: New insights for agency theory. Corporate Governance: An International Review, 17(2), 142-158.

Safiullah, M., \& Shamsuddin, A. (2018). Risk in Islamic banking and corporate governance. Pacific-Basin Finance Journal, 47, 129-149. 
Shafii, Z., Salleh, S., \& Shahwan, S. H. (2010). Management of Shariah non-compliance audit risk in the Islamic financial institutions via the development of Shariah compliance audit framework and Shariah audit programme. Kyoto Bulletin of Islamic Area Studies, 3(2), 3-16.

Shahzad, M. A., Saeed, S. K., \& Ehsan, A. (2017). Sharī'ah Audit and Supervision in Sharī’ah Governance Framework: Exploratory Study of Islamic Banks in Pakistan. Business \& Economic Review, IM Sciences, Peshawar, 9(1), 103-118.

Siddiqui, R. (2010). A Shari'ah scholar's place on the board. Retrieved from https://gulfnews.com/business/a-sharia-scholars-place-on-theboard1.625445\#: :text=Funds\%2Dat\%2DWork\%2C\%20a,than\%20previous\%20Sharia $\% 20$ scholar\%20reports.

Suhartanto, D., Farhani, N. H., \& Muflih, M. (2018). Loyalty Intention towards Islamic Bank: The Role of Religiosity, Image, and Trust. International Journal of Economics \& Management, 12(1), 137-151.

Sulub, S., Salleh, Z., \& Hashim, H. A. (2018). Determinants of corporate governance disclosures of Islamic banks in Sudan: implications for shariah governance. Afro-Asian Journal of Finance and Accounting (Forthcoming).

Sulub, s. a., Salleh, Z., \& Hashim, H. A. (2018a). A review of corporate governance and corporate social responsibility disclosure of Islamic banks: a call for additional transparency. Journal of Sustainability Science and Management, 4, 147-168.

Sulub, S. A., Salleh, Z., \& Hashim, H. A. (2020). Corporate governance, SSB strength and the use of internal audit function by Islamic banks. Journal of Islamic Accounting and Business Research, 11(1), 152-167.

Sulub, Y. A., \& Salleh, M. C. M. (2019). Financial Performance of Islamic and Conventional Banks in Malaysia: A Comparative Analysis. International Journal of Management and Applied Research, 6(4), 375-385.

Thomson Reuters. (2018). Islamic finance development report. Retrieved from https://ceif.iba.edu.pk/pdf/Reuters-Islamic-finance-development-report2018.pdf

Vafeas, N. (1999). Board meeting frequency and firm performance. Journal of Financial Economics, 53(1), 113-142.

Wan Abdullah, W. A. W., Percy, M., \& Stewart, J. (2015). Determinants of voluntary corporate governance disclosure: Evidence from Islamic banks in the Southeast Asian and the Gulf Cooperation Council regions. Journal of Contemporary Accounting \& Economics, 11(3), 262-279. 
Yazkhiruni, Y., Nurmazilah, M., \& Haslida, A. H. (2018). A Review of shariah Auditing Practices in Ensuring Governance in Islamic Financial Institution (IFIs) - A Preliminary Study. Advances in Social Sciences Research Journal, 5(7), 196-210. Retrieved from https://journals.scholarpublishing.org/index.php/ASSRJ/article/view/4873/3022

\section{Copyrights}

Copyright for this article is retained by the author(s), with first publication rights granted to the journal. This is an open-access article distributed under the terms and conditions of the Creative Commons Attribution license (http://creativecommons.org/licenses/by/4.0/) 